\title{
Théâtre et récit. Textes réunis et présentés par Pascale Alexandre-Bergues
}

\section{Emanuele Kanceff}

\section{Q OpenEdition}

1 Journals

\section{Edizione digitale}

URL: http://journals.openedition.org/studifrancesi/30693

DOI: 10.4000/studifrancesi.30693

ISSN: 2421-5856

\section{Editore}

Rosenberg \& Sellier

\section{Edizione cartacea}

Data di pubblicazione: 1 avril 2006

Paginazione: 190

ISSN: 0039-2944

\section{Notizia bibliografica digitale}

Emanuele Kanceff, «Théâtre et récit. Textes réunis et présentés par Pascale Alexandre-Bergues», Studi Francesi [Online], 148 (XLX | I) | 2006, online dal 30 novembre 2015, consultato il 20 avril 2021. URL: http://journals.openedition.org/studifrancesi/30693; DOI: https://doi.org/10.4000/studifrancesi. 30693

Questo documento è stato generato automaticamente il 20 avril 2021.

\section{(c) (1)}

Studi Francesi è distribuita con Licenza Creative Commons Attribuzione - Non commerciale - Non opere derivate 4.0 Internazionale. 


\title{
Théâtre et récit. Textes réunis et présentés par Pascale Alexandre- Bergues
}

\author{
Emanuele Kanceff
}

\section{NOTIZIA}

AA. VV, «Paul Claudel» 19. Théâtre et récit. Textes réunis et présentés par Pascale ALEXANDRE-BERGUES, Paris-Caen, Lettres Modernes Minard, 2005, pp. 170.

1 Questo diciannovesimo numero della serie affronta il tema del teatro, peraltro già esaminato in altri numeri della stessa serie, come il n. 2 sulle differenti versioni di drammi claudeliani, il 5 sugli schemi drammatici, il 6 sulla versione primitiva de $\mathrm{La}$ Ville, il 10 sull'analisi de Le Repos du septième jour, il 9 su Le Soulier de satin, l'11 sullo stesso soggetto. Più specificamente, il tema qui affrontato è il rapporto tra la forma del racconto e quella drammatica, intendendo come teatro non solo i drammi veri e propri ma tutta l'opera teatrale, compresi i libretti per balletto, continuando così l'esplorazione sulle differenti forme drammatiche iniziata nei numeri precedenti. Ci si chiede se il teatro claudeliano, così poco rispettoso delle forme tradizionali, racconti qualche cosa, e che cosa, e come. Fin dall'antichità, il racconto è una delle forme che può assumere il discorso del personaggio, che di fatto assume in scrittori moderni come Beckett e Marguerite Duras. Su questa base i vari studi proseguono mettendo in evidenza la presenza le voci narrative mediatizzate da personaggi,, ricostruendo su di loro l'autoritratto di Claudel, precisando l'aleanza di diegetico e mimetico, i rapportitra tempo raccontato, tempo di raccontare e tempo che racconta. Altri studi sono dedicati all'analisi, in questa direzione, di opere specifiche. 